\title{
Consumer's Green Product Buying Decision: Impact of Selected Factors
}

\author{
R.M.U.M.K. Rathnayaka ${ }^{1}$ \& W.M.N.M. Wijethunga ${ }^{2}$ \\ ${ }^{1,2}$ Department of Business Management \\ Faculty of Business Studies \& Finance \\ Wayamba University of Sri Lanka \\ Kuliyapitiya \\ SRI LANKA \\ $\underline{\text { udithamadushini269@gmail.com }}{ }^{1}$, nisansala@wyb.ac.lk ${ }^{2}$
}

\begin{abstract}
In recent years the concern on environmental issues have become more prominent in both global and local presence. Consequently, the consumers are also paying more attention on environmental products with the increase of environmental awareness. As there is an emerging market segment for green product of Fast Moving Consumer Goods (FMCG) sector in Sri Lanka, marketers could attain the competitive advantage by targeting on this emerging market segment. Consumers have realized that their consumption activities may result in environmental deterioration, which, in turn, may transform and motivate them in making ecologically conscious purchases such as green buying. Consequently, businesses have begun to modify their behaviour in an attempt to address environmental and social issues as a way of their social responsibility and attract consumers towards green products and promote environmental sustainability. The present study was designed to explore how far environment consciousness, eco labeling and green advertising impact on consumer's green product buying decision. Accordingly, 384 respondents of 20-59 age range were selected by convenience sampling method and a structured questionnaire with 23 questions is used to collect data. In this context, results revealed that, green product buying decision was significantly influenced by environment environmental consciousness, eco labels, and green advertising. In practice, marketers of the green products might focus on marketing in order to communicate and enhance the awareness on green product and consumer's environmental concern which might tap the consumers' mindset to prefer the green products. Further Implication of the study might be useful for policy makers to provide incentives to green products manufacturers who are truly green in their manufacturing processes.
\end{abstract}

Keywords-: Environment Consciousness, Eco Labeling, Green Advertising, Green Product 


\section{INTRODUCTION}

Recently, the environmental concern had become an emerging trend due to the massive exposure to environmental problems. According to Moisander (2007) socially responsible consumers are consumers who consider about the public consequences emerged as a result of their private consumption, and attempt to use their purchasing power to bring a social change. Further in aligned with previous studies the majority of consumers have realized that their purchasing behaviour has a direct impact on many ecological problems (Han, Hsu, \& Sheu, 2010).

Moreover, consumers make an effort to familiarize this new threatening situation by considering environmental issues and purchasing more ecologically compatible products or green products. According to Chen and Chai (2010) a green product is a product which has minimum impact on environment and it incorporates these strategies with recycled materials, reduced packing and using less harmful substances. Further green products may satisfy the consumers' needs, preserve the environment and by extension, contributing to sustainability (Joshi and Rahman, 2015).

According to Samarasinghe (2012) as many Asian countries suffering from increasing level of toxic waste, exposure to severe road traffic noise high level of garbage disposal and lessening landfill space in the most of the urban areas. Sri Lanka as an Asian country also experiencing these environmental issues.
It is noticeable that some business sectors like Apparel, Hotel and Tourism and Consumer Goods industries have been adopting ecofriendly business initiatives Samarasinghe and Samarasinghe (2013). Further they stated that, Fast Moving Consumable Goods (FMCG) sector has the large contribution in to the economy and closer to Sri Lankan consumer's day-today lives. Moreover, Samarasinghe and Samarasinghe (2013) stated, that the FMCG sector of the country is concerning about the green marketing issues by incorporating green elements into their marketing mixes as a competitive tool.

Tan, Ojo \& Thurasamy (2019) stated that Consumers have reportedly realized that their consumption activities may result in environmental deterioration, which, in turn, may have transformed and motivated them in making ecologically conscious purchases such as green buying.

Sri Lanka is as Asian society, its environmental quality lags and consumerist movement far behind when compared to the developed countries. But now research evidence suggested that citizens in Asian societies are increasingly becoming conscious of alarming environmental problems. Government policies and business strategies in many Asian countries are being reshaped to give more consideration to long-term sustainable development including environmental protection (Johri and Sahasakmontri, 1998).

Although the term 'green products' had higher attention of people, the real factors affecting green 
purchasing decisions in the Sri Lankan context are not yet discovered empirically. So the study was conducted to achieve following objectives,

1. To examine how far consumers' environmental consciousness influenced on green product buying decision

2. To examine how far eco labeling impact on green product buying decision

3. To examine how far green advertising impact on green product buying decision

4. To examine the combined effect of environment consciousness, eco labeling and green advertising on consumer's green product buying decision.

Green product purchase decision revolves around environmentally concerned consumers who take into account the public consequences of their private consumption behaviour and attempt to use their buying decision to bring about changes (Lai and Cheng, 2016).

The theoretical frame work is supported by two very related theories as Theory of Reasoned Action (TRA) and Theory of Planned Behavior (TPB). TRA model stated that attitude is not necessarily determine the behaviour but it was the intention to determine the behaviour. Ajzen, and Fishbein, (1977).

The TPB is an extension of the TRA and The TPB differs from the TRA since it includes perceived behavioural control (Ajzen, 1991).
As stated by Tan, Ojo \& Thurasamy (2019) the buying decision of green products depends on the consumer's intention to purchase environmentally-friendly products, while avoiding negative impact the environment. Specifically, the consumer's intention maybe conveyed as the willingness to purchase green products. Further Ramayah et al. (2010) explained, intention can be considered as the motivational factors, which may influence consumers' behaviour towards buying/purchasing green products. Moreover, explained purchasing behaviour of green products entails a complex form of ethical decision-making, which requires consumers to act in a socially responsible way when buying products.

Environmental consciousness reflects an individual's knowledge about environmental issues and the impact of environmental-friendly practices in curbing such issues (Boztepe, 2016). In the study of Tan, Ojo \& Thurasamy (2019) stated that environmentally conscious consumers are more likely to indicate protective feelings towards the environment. Therefore, they are willing to change their consumption behaviour to minimize the adverse impact of their actions on the environment, further conceptual model Tan, Ojo \& Thurasamy (2019) suggested that environmental consciousness has a significant impact on green product buying decision

In consistent with previous literature as consumers become more aware of 
the adverse impact of non-sustainable consumption on the environment, they adjust their actions by engaging in environmental protective behaviour. Accordingly, environmental consciousness can influence green buying behaviour among consumers by stimulating them to be socially responsible towards the environment. Hence, the following hypothesis is formulated:

H1: Environmental consciousness, has a significant impact on consumer's green product buying decision

Environmental labels are increasingly being utilized by marketers to promote the identification of green products D'Souza et al., (2006). They stated Eco-label accomplishes two main functions for consumers as information function and value function. Information function that informs them about intangible product characteristics such as product's quality and value function which provide a value in themselves. In the study of Rahbar and Abdul Wahid (2011) Eco label and purchasing behaviour is found to be significant, further Tan, Ojo \& Thurasamy (2019) also suggested that impact of eco label was significant on purchasing behaviour. The discussion in the foregoing, led to the formulation of the following hypothesis.

H2. Eco-label has a significant impact on consumer's buying decision of green products.

The objective of green advertisements is to influence consumers' purchase behavior by encouraging them to buy products that do not harm the environment and to direct their attention to the positive consequences of their purchase behavior (Rahbar \& Abdul Wahid, 2011). According to Phau and Ong (2007), consumers did not only respond to green advertising but also assess the credibility of the advertised brand, further way that message is communicated may effect on the response for advertisements. Mathur and Mathur (2000), stated that credibility of the message may increase the environmental conscious image of the advertisement. Consequently, the following hypothesis is proposed

H3. Green advertising has a significant impact on consumers buying decision of green products

Finally, altogether the study tested how far impact of all the selected factors on green product buying decision.

H4. Environmental consciousness, Eco - Label and Green advertising have significant combined impact on consumer's green product buying decision

Drawing insights from the literature conceptualize that consumers' buying decision of green products largely depends on their environmental consciousness, and key marketing tools such as eco-labelling and advertisements on green products. 


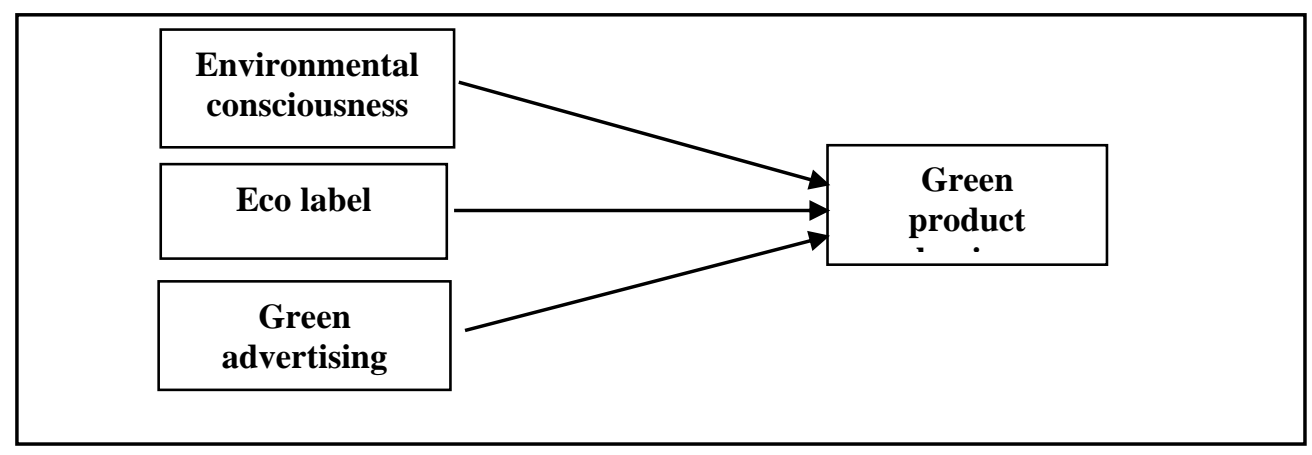

Figure 1: Conceptual framework

\section{METHODS}

The descriptive research design was adopted for the study. The type of the research was deductive and variables were measured with the quantitative analysis. Population was counted as $13,28,654$ out of 20-59 age range (Department of Census and Statistics, Sri Lanka, 2012). And 384 respondents are drawn from Colombo district using the convenience sampling technique (Krejcie \& Morgan,1970). A structured questionnaire with 23 questions was used to collect data by five-point Likert scale to measure the variables under each question from 1 to 5 (1 =strongly disagree, $5=$ strongly agree).

384 questionnaires were returned and considered for the analysis. Pearson correlation was used find the association between dependent and independent variable; multiple regression analysis was utilized to test the hypothesis developed in the study. Further Cronbach Alpha reliability test conducted with SPSS in order to measure the internal consistency of the questionnaire.

\section{RESULTS}

Sample profile summarized as majority of respondents were female respondents $55.2 \%$ out of total of 384 , whereas $44.8 \%$ respondents are male. With regard to age group more than $45 \%(45.6 \%)$ of respondents are aged 20-29 years old. Respondents who represents age of 50-59 were the least representative age category which was only about 24 and $6.3 \%$ out of 384 respondents. In addition, the respondents who were categorized under age of 40-49 represent 55 respondents and 14.3percent out of 384 .

Majority of the respondents are holding a bachelor's degree, they are about 195 and 50.8 percent out of total 384.72 of the respondents have only advanced level and they are about $18.8 \%$ out of total sample. 56 of them are having diploma and 61 of respondents are holding Masters, respective percentage of them are 14.6 and 15.9. Respondents who occupied as executives are about 246 and represents 64 percentages and 75 of respondents are occupied under manager and above level and 
represent 19.5 percentage. 47 of the respondents are trainees and 16 are students with respective percentages of these two groups as 12.2 percent and 4.2 percent.

The overall reliability of the variables was tested with Cronbach alpha value which was greater than $0.7(0.907)$ Therefore all variables related to this study were reliable to conduct study. The degree of association between independent and dependent variable was tested with linear correlation and results are depicted in the table 01 . Pearson Correlation coefficient of the variables were reported respectively as environmental consciousness 0.677 , eco labels 0.715and green advertising 0.624. According to

Multiple regression analysis was used in the present study to determine the impact of critical predictors on the buying decision of green products, as well as to test the five hypotheses. The results of the multiple regression analysis were presented in the tables below.

The overall test results (Table 04) of the regression model suggested that overall regression model was statistically significant $(\mathrm{p}<0.05)$. Further it indicated that Environmental consciousness, Eco Label and Green advertising have significant impact on consumer's green product buying decision and hence $\mathrm{H} 4$ was supported.
Gogtay and Thatte (2017), if correlation coefficient lies between +0.5 and +1 that indicates there is a positive strong relationship between two variables. As the $\mathrm{P}$ value was lesser than 0.05 all three variables study concluded that there is a significant relationship between each independent variable and dependent variable.

Table 1: Correlation results

\begin{tabular}{|l|l|l|}
\hline Predictors & $\begin{array}{c}\text { Pearson } \\
\text { correlation }\end{array}$ & $\begin{array}{c}\text { sig (2- } \\
\text { tailed) }\end{array}$ \\
\hline $\begin{array}{l}\text { Environmental } \\
\text { consciousness }\end{array}$ & .677 & .000 \\
\hline Eco label & .715 & .000 \\
\hline $\begin{array}{l}\text { Green } \\
\text { advertising }\end{array}$ & .624 & .000 \\
\hline
\end{tabular}

Source: Survey data ,2020

The adjusted R2 value of 0.610 (Table 03) indicates that all the supported factors account for about 61 per cent variance in green product buying decision, with eco-label was the most significant predictor.

By examining the significance of the parameter estimates, the present study tested the hypotheses underpinning the research model. As shown in Table 04, the effect of environmental consciousness was significant on buying decision $(\mathrm{b}=0.313 ., \mathrm{p}<$ $0.05)$. Therefore, $\mathrm{H} 1$ is supported. Moreover, eco label was significant on buying decision $(b=0.370, p<$ $0.05)$ and green advertising significant on buying decision $(\mathrm{b}=$ $0.218, \mathrm{p}<0.05$ ) therefore $\mathrm{H} 2, \mathrm{H} 3$ also support. 
Table 2: Model Summary

\begin{tabular}{|l|l|l|l|}
\hline Model & $\mathbf{R}$ & $\begin{array}{l}\text { R } \\
\text { square }\end{array}$ & $\begin{array}{l}\text { Adjusted R } \\
\text { square }\end{array}$ \\
\hline 1 & .783 & .613 & .610 \\
\hline
\end{tabular}

Source: Survey data, 2020

Table 3: ANOVA

\begin{tabular}{|l|l|l|}
\hline Model & f & sig \\
\hline 1 & 200.685 & .000 \\
regression & & \\
residual & & \\
total & & \\
\hline
\end{tabular}

Source: Survey data, 2020

Table 4: Coefficients

\begin{tabular}{|l|l|l|}
\hline Model & $\begin{array}{l}\text { Standard } \\
\text { Coefficient } \\
\text { d }\end{array}$ & Sig \\
\hline constant & & .000 \\
\hline $\begin{array}{l}\text { Environment } \\
\text { consciousness }\end{array}$ & 0.313 & .000 \\
\hline Eco label & 0.370 & .000 \\
\hline $\begin{array}{l}\text { Green } \\
\text { advertising }\end{array}$ & 0.218 & .000 \\
\hline
\end{tabular}

Source: Survey data, 2020

\section{DISCUSSION}

This study investigates the factors of green products buying behaviors among a sample of consumers in Sri Lanka. The regression results suggested consumers' environmental consciousness, eco-label, and advertising positively impact on buying decisions of green products. In consistent with the research study of Tan, Ojo \& Thurasamy (2019) suggested effect of environmental consciousness was significant on buying decision.

In line with the literature, ecolabelling has the most significant positive impact on young consumers buying decision of green products. This indicates a strong interjected motivation among the young consumers, where in, eco-labelling reminds them about environmentfriendly purchasing, which may create the feeling of guilty if they do not buy green products (Ritter et al., 2015).

Findings of the present study determined there is significant impact of green advertising on consumers' buying decision of green products. This aligns with the Phau and Ong's (2007) findings on the importance of advertisement in stimulating consumer's interest towards buying green products. But according to Rahbar \& Abdul Wahid (2011) Environmental advertisement is also another dimension of green marketing tool that is not significant with purchase behavior. Further Kilbourne (1995) suggested one of the factor contributing to the failure of applying environmental advertisements is due to low credibility of green advertisements among 


\section{CONCLUSION}

Sri Lankan consumers possess environmental consciousness and they actively support the environment by purchasing and consuming products which are known to be environmentally friendly, this was supported by accepting H1, Consumers environmental consciousness have significant impact on green product buying decision. According to the findings of the present study Eco label is the highest influential variable that impact on green product buying decision. FMCG companies could use ecolabels as tools to indicate and communicate the environmental performance of a product with the aim of supporting consumer decisionmaking for environmentally friendly products, by providing transparency and enhancing trust in the environmental identities of products. Further it is evident from the findings of the study that the fundamental purpose of green advertisements is to offer green product experience to consumers, and it motivates consumers to be aware and owe the product. Finally, the study provides evidences for, Marketers in FMCG industry to enhance the green product experience of consumers by understanding impact of consumers environment consciousness, Eco labeling efforts and advertising efforts towards the buying decision of green product

\section{REFERENCES}

Ajzen, I. and Fishbein, M. (1977) Attitude-behaviour relations: a theoretical analysis and review of empirical research,
Psychological Bulletin, 84(5), 888-918.

Ajzen, I. (1991). The theory of planned behavior. Organizational Behavior and Human Decision Processes, 50(2), 179-211.

Boztepe, A. (2016).Green marketing and its impact on consumer buying behavior, European Journal of Economic and Political Studies, 5(1), 5-21.

Chen TB, Chai LT (2010). Attitude towards the environment and green products, Consumers perspective. Management Science and Engineering, 4(2).27-39.

D'Souza, C., Taghian, M., \& Lamb, P. (2006). An empirical study on the influence of environmental labels on consumers. Corporate Communications: $A n$ International Journal, 11(2), 162-173.

Gogtay, N. J. and Thatte, U. M. (2017), Principles of correlation Analysis, Journal of The Association of Physicians of India, 65 (March), 78-81.

Han, H., Hsu, L. T. J., \& Sheu, C. (2010). Application of the theory of planned behavior to green hotel choice: Testing the effect of environmental friendly 
activities.

Tourism

Management, 31(3), 325334

Johri, L. M, Sahasakmontri, K. (1998). Green marketing of cosmetics and toiletries in Thailand. Journal of Consumer Marketing, 15 (3), 265-281.

Joshi, Y., \& Rahman, Z. (2015). Factors Affecting Green Purchase Behaviour and Future Research Directions. International Strategic Management Review, 3(1-2), 128-143.

Kilbourne, W. (1995). Green Advertising: Salvation or Oxymoron.Journal Advertising, 24(2), 7-20.

Lai, C., \& Cheng, E. (2016). Green purchase behavior of undergraduate students in Hong Kong. The Social Science Journal, 53(1), 67-76.

Moisander, J., 2007. Motivational complexity of green consumerism. International Journal of Consumer Studies, 31(4), pp.404-409.

Mathur, L., \& Mathur, I. (2000). An Analysis of the Wealth Effects of Green Marketing Strategies. Journal of Business Research, 50(2), 193-200.

Krejcie, R. V., \& Morgan, D. W. (1970). Determining sample size for research activities.

Educational and psychological measurement, 30(3), 607-610.

Phau, I., \& Ong, D. (2007). An investigation of the effects of environmental claims in promotional messages for clothing brands. Marketing Intelligence \& Planning, 25(7), 772-788.

Ramayah, T., Wai, J., Lee, C. and Mohamad, O. (2010), Green product purchase intention: some insights from a developing country. Resources, Conservation \& Recycling, 54, 1419- 1427.

Rahbar, E., \& Abdul Wahid, N. (2011). Investigation of green marketing tools' effect on consumers' purchase behavior. Business Strategy Series, 12(2), 73-83. .

Ritter, Á, Borchardt, M., Vaccaro, G., Pereira, G., \& Almeida, F. (2015). Motivations for promoting the consumption of green products in an emerging country: exploring attitudes of Brazilian consumers. Journal of Cleaner Production, 106, 507-52.

Samarasinghe, D. S. (2012). Green awaking or not: Investigating pro-environmental behaviour intention of Sri Lankan Consumers. Quest-Journal of Management and Research, 2(2), 3-12. 
Samarasinghe, G., \& Samarasinghe, D. (2013). Green decisions: consumers' environmental beliefs and green purchasing behaviour in Sri Lankan context. International Journal of Innovation and Sustainable Development, 7(2), 172.

Sekaran U. Research methods for business. A skill building approach. New York: Wiley; 2003.

Tan, C., Ojo, A., \& Thurasamy, R. (2019). Determinants of green product buying decision among young consumers in Malaysia. Young Consumers, 20 (2), 121137.

Wanninayake, W.M.C.B. and Randiwela, P. (2008) 'Consumer attractiveness towards green products of FMCG sector: an empirical study', Oxford Business and Economics Conference Program, 22-24 June, Oxford, UK 